\title{
Comparative in vitro study of intracanal Enterococcus faecalis reduction using photosensitizers in aPDT
}

\author{
Maria Cleide Azevedo Braz ${ }^{1}$ iD, André Hayato \\ Saguchi $^{2}$ (ID) Eduardo Akisue ${ }^{3}$ (iD, Adriana de Oliveira \\ Lira $^{2}$ (D), Sidnea Aparecida Freitas Paiva² (iD, Aldo \\ Brugnera Junior ${ }^{4}$ iD, Mary Caroline Skelton \\ Macedo $^{5}$ iD, André Luiz da Costa Michelotto ${ }^{6}$ iD, \\ Ângela Toshie Araki ${ }^{2 *}$ iD
}

${ }^{1}$ Federal University of Patos, Patos, PB, Brazil.

${ }^{2}$ Cruzeiro do Sul

University, São Paulo, SP, Brazil.

${ }^{3}$ Santa Cecilia University, Santos, SP, Brazil.

${ }^{4}$ Camilo Castelo Branco University, São Paulo, SP, Brazil.

${ }^{5}$ Dentistry Department at University of São Paulo, SP, Brazil.

${ }^{6}$ Federal University of Paraná, Curitiba, PR, Brazil.

Corresponding author: Ângela Toshie Araki

Av Robert Kennedy 2126/sala 4, ZIP CODE 09861-080 - São Bernardo do Campo, SP Brazil

Tel.: +55-11-992534078 Fax:

+55-11-43921575

a_araki@me.com

Editor: Dr Altair A. Del Bel Cury

Received: January 20, 2021

Accepted: May 25, 2021
Aim: To compare Enterococcus faecalis reduction after antimicrobial photodynamic therapy (aPDT) used with methylene blue, toluidine blue, tannin, and curcumin as photosensitizers, an adjunct to endodontic chemomechanical preparation (CMP) in root canals of human teeth. Methods: A total of 120 single-rooted teeth were divided into 6 groups $(n=20)$ : G1- CMP and 2.5\% sodium hypochlorite ( $\mathrm{NaOCl}$ ); G2- CMP and saline solution; G3- CMP, 2.5\% NaOCl, and APDT with $0.005 \%$ methylene blue; G4- CMP, $2.5 \% \mathrm{NaOCl}$, and aPDT with $0.005 \%$ toluidine blue; G5- CMP, $2.5 \% \mathrm{NaOCl}$, and aPDT with $0.005 \%$ tannin; and G6- CMP, $2.5 \% \mathrm{NaOCl}$, and aPDT with $0.005 \%$ curcumin. A portable semiconductor laser was used (660 nm, $100 \mathrm{~mW}, 1.8 \mathrm{~J}, 180 \mathrm{~s}$ ) in groups 1, 2, 3, 4, 5, and a blue LED light-curing $\left(420-480 \mathrm{~nm}, 1200 \mathrm{mV} / \mathrm{cm}^{2}\right)$ in G6. For all groups, a 5 min pre-irradiation time was applied. Samples were collected before (initial collection), immediately after (intermediate collection) and 7 days after CMP (final collection) for colony-forming unit (CFU) counting. The Kruskal-Wallis test and analysis of variance (ANOVA) were performed ( $p<0.05 ; 95 \%$ confidence interval). Results: In between-group comparisons, there was no significant difference observed in the number of CFUs at the initial $(p<0.001)$ and final collections $(p<0.001)$ for G2 and G3. In within-group comparisons, the number of CFUs showed a decreasing trend in G4 $(p=0.007)$ and $G 5(p=0.001)$. Conclusion: Photosensitizers promoted E. faecalis reduction, with better results for tannin and curcumin. Alternative photosensitizers should be the focus of further studies.

Keywords: Photodynamic. Endodontics. Photosensitizing agents. Curcumin. Tannins. 


\section{Introduction}

The main goal of endodontic treatment is to eliminate or reduce the intraradicular microbial load to a level that allows for the prevention or cure of apical periodontitis ${ }^{1}$. The development and/or persistence of apical periodontitis is closely related to the presence of microorganisms within the root canal, and insufficient root canal disinfection has been suggested as one of the main reasons for treatment failure ${ }^{2}$.

In addition to auxiliary chemicals, intracanal medicaments, passive ultrasonic irrigation, magnification, and ultrasound, antimicrobial photodynamic therapy (aPDT) has also been used as an adjunct to conventional endodontic treatment ${ }^{3-5}$. aPDT requires a photosensitizer and a light source emitting at a wavelength close to its absorption peak that will absorb energy from light photons ${ }^{6}$. The photosensitizing agent binds to the microorganism membrane or cell wall or accumulates selectively in them, becoming target to the light irradiated. In the presence of oxygen, photosensitizers generate reactive oxygen species (ROS) - singlet oxygen and free radicals - that, by oxidative reactions, can lead to death of various organisms- fungi, viruses, protozoa and bacteria?

Photosensitizers initially act on the cell membrane to increase cell permeability, and then penetrate the cell acting on other intracellular organelles ${ }^{8}$. Methylene blue and toluidine blue, at low concentrations, have been widely used as photosensitizers for not exerting cytotoxic effects on keratinocytes and fibroblasts ${ }^{9}$. Tannins and curcumin are also used in aPDT. Tannins are astringent, hemostatic, polyphenolic compounds that have been used as natural dyes and are major active constituents of plants, which justifies the traditional use of plants as anti-inflammatory and healing agents ${ }^{10}$. They have a strong absorption band at $672 \mathrm{~nm}$ and rapid skin clearance. Tannins are non-toxic and have favorable photophysical properties, with high triplet-state yields. Curcumin, a polyphenolic compound extracted from Curcuma Longa rhizomes, has been widely used in traditional Chinese medicine and food industry, with anti-inflammatory, antitumor, antifungal, antibacterial, and anticarcinogenic properties ${ }^{11}$. In aPDT, curcumin has high light absorption capacity at wavelengths in the blue spectral region, between $455 \mathrm{~nm}$ and $492 \mathrm{~nm}^{12}$ which is commonly used in dental offices for the light curing of resin-based composites by using a LED or halogen light device.

Reduction of intracanal microorganisms promoted by aPDT ranges from 65 to $99.6 \%$ depending on the photosensitizer used, and some studies have been conducted to compare the reducing ability of photosensitizers ${ }^{12,13}$. This way, in this study had compared methylene blue, toluidine blue, tannin, and curcumin for their ability to reduce intracanal Enterococcus faecalis.

The purpose of this study was to compare microbial reduction after aPDT (660nm) used with methylene blue, toluidine blue, tannin, and curcumin as photosensitizers as an adjunct to chemomechanical preparation (CMP) in root canals of human teeth contaminated with $E$. faecalis. 


\section{Materials and Methods}

\section{Study design and setting}

This in vitro study was conducted after approval by the institutional research ethics committee (approval number 2.332.759). The sample size was calculated using G*Power, version 3.1, based on a pilot data set to obtain a medium to large effect size, with a significance level of 5\%,95\% confidence interval $(\mathrm{Cl})$, statistical power of $80 \%(\beta=0.20)$, and a 1:1 allocation ratio. A sample size of 20 specimens per group was required.

\section{Specimen preparation}

A total 120 extracted single-rooted mandibular incisors with fully formed apices were selected for this study. All teeth had been donated to the human tooth bank of our institution, and written informed consent was obtained from all patients prior to tooth donation. After periodontal tissue removal and rubber cup and pumice prophylaxis, the crowns were removed with a diamond disc. The remaining 12-mm roots were autoclaved at $120^{\circ} \mathrm{C}, 1 \mathrm{~atm}$, for $20 \mathrm{~min}$, and the apical third were sealed with Araldite epoxy resin (Brascola, São Paulo, SP, Brazil) to prevent leakage of bacterial cultures after contamination.

\section{Microorganisms and culture medium}

The root canals were contaminated with a pure culture of E. faecalis (ATCC 29212) in brain heart infusion (BHI) broth (BHI00- Oxoid; Basinkstoke, UK). Isolated colonies were suspended in screw-cap tubes containing $5 \mathrm{~mL}$ of BHI broth. The suspension was mechanically shaken and adjusted in a spectrophotometer with absorbance at $800 \mathrm{~nm}$ to match a $1.0 \mathrm{McF}$ arland standard $\left(3.0 \times 10^{8}\right.$ bacteria/mL). The specimens were transferred to flasks containing sterile $\mathrm{BHI}$ broth and remained incubated at $37^{\circ} \mathrm{C}$ for $24 \mathrm{~h}$ to confirm sterility.

\section{Contamination with $\mathrm{E}$. faecalis}

In a laminar flow hood, $5.0 \mathrm{~mL}$ of $\mathrm{BH}$ broth were removed and replaced with $4.0 \mathrm{~mL}$ of $E$. faecalis suspension. The flasks containing the specimens were sealed and incubated at $37^{\circ} \mathrm{C}$ in a $10 \% \mathrm{CO}_{2}$ atmosphere for 7 days, with $2.0 \mathrm{~mL}$ of contaminated $\mathrm{BHI}$ broth being replaced with $2.0 \mathrm{~mL}$ of sterile $\mathrm{BHI}$ broth every 2 days to avoid medium saturation. Bacterial growth during incubation was determined by turbidity of the culture medium.

\section{Experimental groups}

The 120 specimens were divided into 6 groups $(n=20)$ according to the disinfection protocol used during CMP, as shown in Table 1. 
Table 1. Groups distribution

\begin{tabular}{llc}
\hline & N & DISINFECTION PROTOCOL \\
\hline G1(Control) & 20 & CMP + 2.5\% Sodium hypochlorite \\
\hline G2(Control) & 20 & CMP + Saline solution \\
\hline G3 & 20 & CMP + Methylene blue + aPDT \\
\hline G4 & 20 & CMP + Toluidine blue + aPDT \\
\hline G5 & 20 & CMP + Tannin + aPDT \\
\hline G6 & 20 & CMP + Curcumin + aPDT \\
\hline
\end{tabular}

\section{Chemomechanical preparation and photodynamic therapy}

The teeth were arranged in a table-top lathe machine and prepared with a size 35.06 WaveOne Gold file (Dentsply). All root canals were prepared and irrigated with $10 \mathrm{~mL}$ of $2.5 \%$ sodium hypochlorite ( $\mathrm{NaOCl}$ ), followed by irrigation with $10 \mathrm{~mL}$ of saline solution, except group 2 that irrigation was realized with saline solution. In groups submitted to aPDT after instrumentation, the canals were irrigated with photosensitizers solution ( $3 \mathrm{~mL}$ ) of $0.005 \%$ with a 5 -min pre-irradiation period. Portable semiconductor

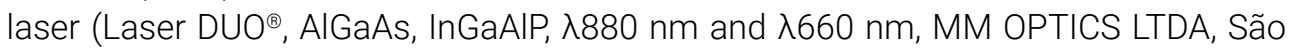
Carlos, SP, Brazil) was used at a wavelength of $660 \mathrm{~nm}, 100 \mathrm{~mW}$ output power, and laser beam area of $3 \mathrm{~mm}^{2}$, for a total energy of $1.8 \mathrm{~J}$ per spot area over an irradiation time of 180s. In final, the canals were irrigated with $10 \mathrm{~mL}$ of saline solution to remove the dyes according to the protocol of Gomes et al. ${ }^{14}$ In group 6, aPDT irradiation was performed with a blue LED light-curing unit (Gnatus), at a wavelength of 420-480 nm, with an intensity of $1200 \mathrm{mV} / \mathrm{cm}^{2}$.

\section{Microbiologic collection}

Samples were collected at 3 time points: before CMP (initial collection), immediately after CMP (intermediate collection), and 7 days after CMP (final collection). All procedures were performed in a laminar flow hood.

\section{Initial collection}

Before CMP, the specimens were irrigated with $10 \mathrm{~mL}$ of saline solution, dried with $15-\mathrm{mm}$ diameter sterile paper points for 1 min (Figure 1), and stored in Eppendorf tubes (Figure 2).

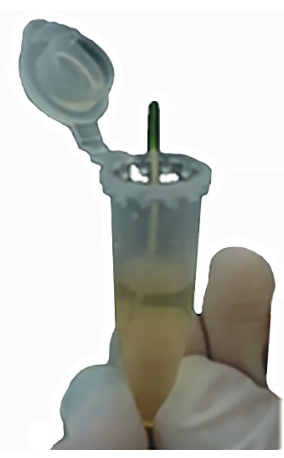

Figure 1. Microbiologic collection with a sterile paper point. 


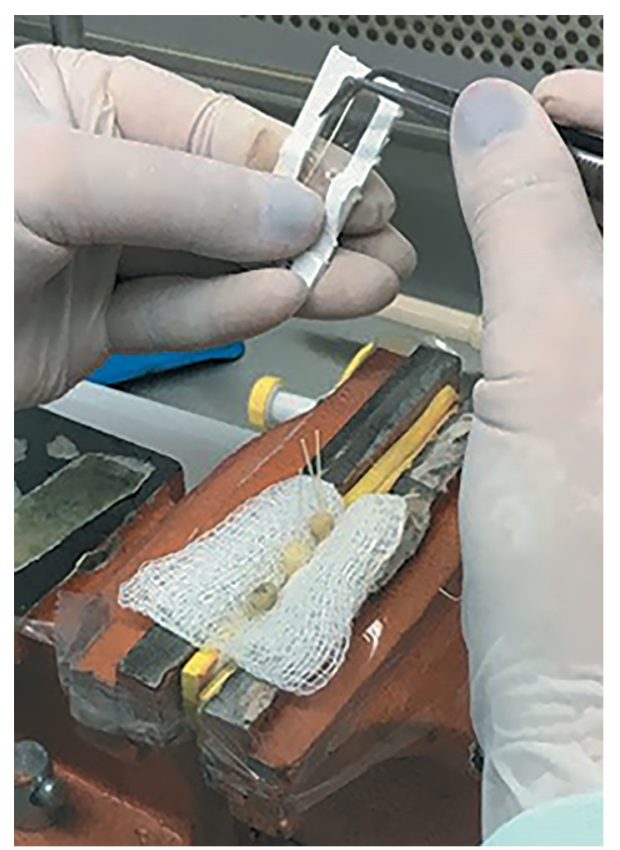

Figure 2. Eppendorf tube with the paper point after collection

\section{Intermediate collection}

CMP was performed after the initial collection, and the canals were dried with sterile paper points and stored individually in Eppendorf tubes, following the same protocol used for the initial collection. The specimens were filled with BHI broth and sealed with a gutta-percha stick to prevent contamination. The specimens were placed in individual Eppendorf tubes containing $60 \mu \mathrm{L}$ of sterile $\mathrm{BHI}$ broth to maintain hydration, so that the BHI broth did not reach the middle third of the canal to prevent infiltration into the gutta-percha sealing. The tubes were incubated at $37^{\circ} \mathrm{C}$ in a $10 \% \mathrm{CO}_{2}$ atmosphere for 7 days.

\section{Final collection}

After 7 days, the root canals were again irrigated with $10 \mathrm{~mL}$ of saline solution, dried with 35-mm diameter sterile paper points, and placed in individual Eppendorf tubes containing $1 \mathrm{~mL}$ of sterile BHI broth. After collection, the Eppendorf tubes were vortexed (Biomixer-QL-901) for $60 \mathrm{~s}$ to homogenize the solution.

\section{Dilution and plating}

After mechanical agitation, the collected samples were diluted 1:10 and 1:100 in sterile $\mathrm{BHI}$ broth. $\mathrm{A} 50-\mu \mathrm{L}$ aliquot of the $10^{-2}$ dilution was seeded on plates containing $\mathrm{BHI}$ agar, in triplicate, and the plates were incubated at $37^{\circ} \mathrm{C}$ in a $10 \% \mathrm{CO}_{2}$ atmosphere. After $48 \mathrm{~h}$, colonies on plates were counted to determine the colony-forming units (CFUs). The number of CFUs was multiplied by 2000 to account for dilutions during sample preparation (100 times) and $50-\mu \mathrm{L}$ plating (20 times less than $1 \mathrm{~mL}$ ), thus yielding the number of CFUs per $\mathrm{mL}$ of sample (CFU/mL). The average of the 3 plates of each collection was taken as the final count (Figure 3). 


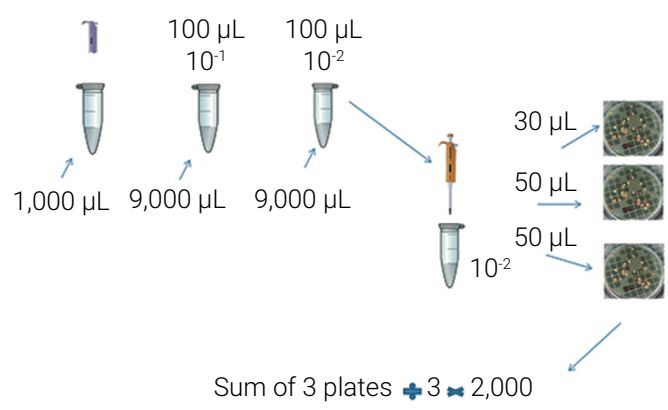

Figure 3. Schematic representation of microbiologic collection in the initial, intermediate, and final stages

\section{Statistical analysis}

Data were analyzed using BioStat 4.0. The Shapiro-Wilk test was used to assess the normality of data distribution. The Kruskal-Wallis test and analysis of variance (ANOVA) were used for nonparametric data, at a significance level of $p<0.05$ and $95 \% \mathrm{Cl}$.

\section{Results}

Table 2 shows the results of the comparative analysis of bacterial load $(\mathrm{CFU} / \mathrm{mL})$ in each group at the 3 assessment time points. In between-group comparisons, a significant difference was observed in the number of CFUs at the initial $(p<0.001)$ and final collections $(p<0.001)$. In within-group comparisons, the number of CFUs showed a decreasing trend in groups $4(p=0.007)$ and $5(p=0.001)$. When comparing initial and final values, percentage reductions in relation to mean CFUs were $68.2 \%$ for group 4 and $69.9 \%$ for group 5 .

Table 2. Comparison of bacterial load at 3 assessment time points

\begin{tabular}{|c|c|c|c|c|c|c|c|}
\hline \multirow{2}{*}{ Time point } & \multicolumn{6}{|c|}{ Group } & \multirow[b]{2}{*}{ p-value ${ }^{(1)}$} \\
\hline & G1 & G2 & G3 & G4 & G5 & G6 & \\
\hline \multicolumn{8}{|l|}{ Initial Collection } \\
\hline Mean & $116,36^{\mathrm{A}, \mathrm{Ba}}$ & 8,37 Аа & $225,12^{\mathrm{Ba}}$ & $269,66^{\mathrm{Ba}}$ & $272,30^{\mathrm{Ba}}$ & 267,39 ва & $<0,001$ * \\
\hline SD & 207,46 & 9,46 & 215,97 & 283,75 & 259,81 & 286,61 & \\
\hline \multicolumn{8}{|l|}{ Intermediate Collection } \\
\hline Mean & $31,73^{\text {Аа }}$ & $85,00^{\text {Aa }}$ & $74,26^{\mathrm{Ab}}$ & $192,92^{\mathrm{Aa}, \mathrm{b}}$ & $54,67^{A b}$ & $292,07^{\text {Аа }}$ & $<0,078$ \\
\hline SD & 35,23 & 200,93 & 66,68 & 209,94 & 88,20 & 408,84 & \\
\hline \multicolumn{8}{|l|}{ Final Collection } \\
\hline Mean & $74,34^{\mathrm{A}, \mathrm{Ba}}$ & $1856719,65^{\mathrm{Bb}}$ & $272,40^{\mathrm{Ca}, \mathrm{b}}$ & $85,77^{\mathrm{A}, \mathrm{Bb}}$ & $81,83^{\mathrm{A}, \mathrm{Bb}}$ & $12,23^{\text {Аа }}$ & $<0,001$ * \\
\hline SD & 159,94 & 8303252,97 & 280,49 & 91,62 & 164,47 & 18,38 & \\
\hline$p$-valor ${ }^{(2)}$ & 0,630 & $<0,001 *$ & $0,007 *$ & $0,007 *$ & $0,001 *$ & 0,089 & \\
\hline \% inhibition (initial-final) & $36,1 \%$ & - & - & $68,2 \%$ & $69,9 \%$ & $95,4 \%$ & \\
\hline
\end{tabular}

$\mathrm{SD}=$ standard deviation; values with different superscript letters are significantly different $(p<0.05) ;{ }^{(1)}$ uppercase letters compare values in the same row (between-group comparisons); (2) lowercase letters compare values in the same column (within-group comparisons). 
The control group 2 (with saline) and group 3 (with methylene blue) showed no reduction in CFUs. All other groups showed bacterial reduction between the initial and final collections, but group 6 (with curcumin) had a marked standard deviation, and the result was not statistically significant.

\section{Discussion}

E. faecalis is a valuable microbiologic marker for in vitro studies because of its ability to colonize the root canal in a biofilm-like style ${ }^{2}$. In addition, E. faecalis does not require strict culture conditions: it grows in culture media supplemented with blood or serum ${ }^{15}$, justifying the use of $\mathrm{BHI}$ agar as a culture medium, as previously done by Silva Garcez et al. ${ }^{16}$ (2006). The incubation period was 7 days, according to Dametto et al. ${ }^{17}$ (2005).

The procedures for microbiologic collection vary between studies. Bonsor et al. ${ }^{18}$ (2006) used an endodontic file to remove dentin debris from the root canal and this instrument together with the swarf sample (dentin debris) was analyzed, while Soukos et al. ${ }^{19}$ (2006) and Fimple et al. ${ }^{9}$ (2008) analyzed the solution leaking from the apical foramen. In the present study, microbiologic samples were collected from within the root canal by using sterile paper points, according to previous studies $14,16,20,21$.

In all groups, the auxiliary chemical used was $2.5 \% \mathrm{NaOCl}$, because its bactericidal effect and ability to dissolve necrotic and living tissues ${ }^{22,23}$. In control group 1 (CMP with $2.5 \% \mathrm{NaOCl}$ ), there was only a $36.1 \%$ reduction in bacterial growth, which was not statistically significant $(p=0.63)$. Higher concentration of $\mathrm{NaOCl}$ would improve its properties ${ }^{24-26}$ but increase the risk of accidents ${ }^{27}$ because substances are less biocompatible with peri radicular tissues ${ }^{24,28}$. Increasing the volume of the solution to compensate for the effects of concentration ${ }^{22,29-32}$ would improve its bactericidal properties.

The present study compared the efficacy in reducing $E$. faecalis of 4 dyes used as photosensitizers in aPDT: methylene blue, toluidine blue, tannin, and curcumin. Methylene blue is the most commonly used dye in endodontics ${ }^{9,19}$, followed by toluidine blue ${ }^{14,18,20,21}$. They are known to be more effective against gram-positive than gram-negative species ${ }^{33}$. Methylene blue is used at various concentrations, ranging from $1 \mu \mathrm{g} / \mathrm{mL}$ to $25 \mu \mathrm{g} / \mathrm{mL}$, as is toluidine blue, ranging from $12.5 \mu \mathrm{g} / \mathrm{mL}$ to $100 \mu \mathrm{g} /$ $\mathrm{mL}$. In accordance with the study by Gomes et al. ${ }^{14}$ (2008) the 4 photosensitizers tested in this study were used at a concentration of $5 \mu \mathrm{g} / \mathrm{mL}$ (0.005\%). An unexpected statistically significant $(p<0.001)$ bacterial growth was observed between the initial and final collections using methylene blue. However, when a higher concentration was used there was a reduction of $80 \%{ }^{9}$ and $97 \%{ }^{19}$. Besides to the concentration, better results could also be achieved using more energy density of light $\left(\mathrm{J} / \mathrm{cm}^{2}\right)^{9}$ and combining it with passive ultrasonic irrigation ${ }^{34,35}$. In contrast to methylene blue, toluidine blue at a concentration of $0.005 \%$ promoted a statistically significant reduction of $68.2 \%$, in accordance with other studies ${ }^{12,18,36}$.

Extracted from guava leaves (Psidium guajava L. Myrtaceae), 'espinheira-santa' leaves (Maytenus sp., Celastraceae), and Brazilian peppertree leaves (Schinus terebinthifolius Raddi), tannins are astringent, hemostatic substances ${ }^{37}$ commonly used in the leather tanning industry and paint industry. The hydrolyzable tannins have aroused the interest of researchers to be tested against microorganisms that infect the root canal sys- 
tem because they are non-toxic and have favorable photophysical properties with high triplet-state yields ${ }^{9}$. The use of tannin in Group 5 promoted a statistically significant bacterial reduction of $69.9 \%(p=0.001)$, better than groups 3 and 4 (methylene blue and toluidine blue, respectively) and group 1 ( $\mathrm{NaOCl}$ alone). According to Verza et al. ${ }^{38}$ (2012) hydrolyzable tannins have a stable binding to central glycose residues and consequently increased solubility and binding of its molecules to low-density lipoproteins, facilitating entry into the target cell.

Given the $69.9 \%$ bacterial load reduction and results superior to those of methylene blue and toluidine blue, the present authors hypothesize that tannin may be indicated in cases of persistent $E$. faecalis infection. Tannins are easily extracted from plants such as guava tree, 'espinheira-santa' (Maytenus sp., Celastraceae), and Brazilian peppertree at a low cost. So, they have become a highly promising dye for use in aPDT. Curcumin is a pigment extracted from Curcuma Longa, a plant used as a spice in cuisine that also has anti-inflammatory, antitumor, antifungal, antibacterial, and anticarcinogenic properties, in addition to antiviral effects against hepatitis $B$ and $\mathrm{H} 1 \mathrm{~N} 1$ viruses. It has an antimicrobial effect against gram-negative and gram-positive bacteria when used in aPDT and can be purchased at a compounding pharmacy. Curcumin has the advantage of being activated by a blue spectral range between $455 \mathrm{~nm}$ and $492 \mathrm{~nm}$, which allows for the use of LED or halogen light devices ${ }^{12}$. In this study, the curcumin group (Group 6) showed a marked standard deviation and the 95,4\% bacteria reduction was not statistically significant. Da Frota et al. ${ }^{12}$ (2015) evaluated the efficacy of aPDT using curcumin in the elimination of Enterococcus faecalis from root canals, varying the time of LED irradiation ( 5 or $10 \mathrm{~min}$ ) after 5 min of pre-irradiation time. They observed that 5 min reduced more bacterial viability than 10 min LED irradiation. Mahdi et al. ${ }^{39}$ (2015) investigated the effect of aPDT using a combination of curcumin $(60 \mu \mathrm{M}), \mathrm{H} 2 \mathrm{O} 2(0.3 \mathrm{mM})$, and erythrosine $(22 \mu \mathrm{M})$ in planktonic cultures of Porphyromonas gingivalis and Fusobacterium nucleatum and observed a 100\% bacterial reduction after $5 \mathrm{~min}$ of blue light activation $(450 \mathrm{~nm})$.

In sum, the control group 2 (CMP with saline) and group 3 (CMP + aPDT with methylene blue) showed no reduction in CFUs. All other groups showed bacterial reduction between the initial and final collections, but group 6 (CMP + aPDT with curcumin) had a marked standard deviation and a not statistically significant reduction. Group 5 (CMP + aPDT with tannin) showed the best results, introducing tannin as an alternative dye with less toxicity and good antibacterial activity.

Despite the fact of all advances in rotary and reciprocating instruments, microbiology should always be the focus of endodontic treatment. It is well- known these instruments become instrumentation of radicular canal faster, reducing clinical time. In addition, studies have shown effectiveness of these instruments systems on microbial reduction ${ }^{40}$. However, the present authors have a concern if clinicians and specialists are, in fact, irrigating successfully in such reduced clinical time. aPDT emerges in this scenario improving and ensuring microbial load reducton inside radicular system canal. This study presents tannin and curcumin as alternatives to methylene blue and toluidine blue, showing promising results. However, randomized controlled trials are warranted to further test them in APDT given their scientific relevance. Alternative photosensitizers and other concentrations in APDT should be the focus of further in vitro and in vivo studies. 
In conclusion, aPDT using a wavelength of $660 \mathrm{~nm}, 100 \mathrm{~mW}$ as light source during 180 s in association with toluidine blue or tannin at a $0.005 \%$ concentration used as an adjunct to CMP with $2.5 \% \mathrm{NaOCl}$ reduced E. faecalis significantly. Methylene blue at a $0.005 \%$ concentration and curcumin did not promote microbial reduction.

\section{Author Disclosure Statement}

Financial disclosure: The authors have no financial relationships relevant to this article to disclose

Conflict of Interest: No competing financial interests exist.

\section{References}

1. Orstavik D. Time-course and risk analyses of the development and healing of chronic apical periodontitis in man. Int Endod J. 1996 May;29(3):150-5. doi: 10.1111/j.1365-2591.1996.tb01361.x.

2. Asnaashari M, Ashraf H, Rahmati A, Amini N. A comparison between effect of photodynamic therapy by LED and calcium hydroxide therapy for root canal disinfection against Enterococcus faecalis: a randomized controlled trial. Photodiagnosis Photodyn Ther. 2017 Mar;17:226-32. doi: 10.1016/j.pdpdt.2016.12.009.

3. Pinheiro SL, Silva CCD, Silva LAD, Cicotti MP, Bueno CEDS, Fontana CE, et al. Antimicrobial efficacy of $2.5 \%$ sodium hypochlorite, $2 \%$ chlorhexidine, and ozonated water as irrigants in mesiobuccal root canals with severe curvature of mandibular molars. Eur J Dent. 2018 Jan-Mar;12(1):94-9. doi: 10.4103/ejd.ejd_324_17.

4. Kim S, Baek S. The microscope and endodontics. Dent Clin North Am. 2004 Jan;48(1):11-8. doi: 10.1016/j.cden.2003.12.001.

5. Pourhajibagher M, Bahador A. Adjunctive antimicrobial photodynamic therapy to conventional chemo-mechanical debridement of infected root canal systems: A systematic review and meta-analysis. Photodiagnosis Photodyn Ther. 2019 Jun;26:19-26. doi: 10.1016/j.pdpdt.2019.02.009.

6. Bouillaguet S, Wataha JC, Zapata O, Campo M, Lange N, Schrenzel J. Production of reactive oxygen species from photosensitizers activated with visible light sources available in dental offices. Photomed Laser Surg. 2010 Aug;28(4):519-25. doi: 10.1089/pho.2009.2505.

7. Ricci Donato HA, Pratavieira S, Grecco C, Brugnera-Júnior A, Bagnato VS, Kurachi C. Clinical Comparison of Two Photosensitizers for Oral Cavity Decontamination. Photomed Laser Surg. 2017 Feb;35(2):105-10. doi: 10.1089/pho.2016.4114.

8. Lambrechts SA, Aalders MC, Van Marle J. Mechanistic study of the photodynamic inactivation of Candida albicans by a cationic porphyrin. Antimicrob Agents Chemother. 2005 May;49(5):2026-34. doi: 10.1128/AAC.49.5.2026-2034.2005.

9. Fimple JL, Fontana CR, Foschi F, Ruggiero K, Song X, Pagonis TC, Tanner AC, Kent R, Doukas AG, Stashenko PP, Soukos NS. Photodynamic treatment of endodontic polymicrobial infection in vitro. J Endod. 2008 Jun;34(6):728-34. doi: 10.1016/j.joen.2008.03.011.

10. Asongalem EA, Foyet HS, Ngogang J, Folefoc GN, Dimo T, Kamtchouing P. Analgesic and antiinflammatory activities of Erigeron floribundus. J Ethnopharmacol. 2004 Apr;91(2-3):301-8 doi: 10.1016/j.jep.2004.01.010.

11. Moghadamtousi SZ, Kadir HA, Hassandarvish P, Tajik H, Abubakar S, Zandi K. A review on antibacterial, antiviral, and antifungal activity of curcumin. Biomed Res Int. 2014;2014:186864. doi: 10.1155/2014/186864. 
12. da Frota MF, Guerreiro-Tanomaru JM, Tanomaru-Filho M, Bagnato VS, Espir CG, Berbert FL. Photodynamic therapy in root canals contaminated with Enterococcus faecalis using curcumin as photosensitizer. Lasers Med Sci. 2015 Sep;30(7):1867-72. doi: 10.1007/s10103-014-1696-z.

13. Pourhajibagher M, Kazemian H, Chiniforush N, Hosseini N, Pourakbari B, Azizollahi A, et al. Exploring different photosensitizers to optimize elimination of planktonic and biofilm forms of Enterococcus faecalis from infected root canal during antimicrobial photodynamic therapy. Photodiagnosis Photodyn Ther. 2018 Dec;24:206-11. doi: 10.1016/j.pdpdt.2018.09.014.

14. Gomes BP, Pinheiro ET, Jacinto RC, Zaia AA, Ferraz CC, Souza-Filho FJ. Microbial analysis of canals of root-filled teeth with periapical lesions using polymerase chain reaction. $J$ Endod. 2008 May;34(5):537-40. doi: 10.1016/j.joen.2008.01.016.

15. Simonsen GS, Småbrekke L, Monnet DL, Sørensen TL, Møller JK, Kristinsson KG, et al. Prevalence of resistance to ampicillin, gentamicin and vancomycin in Enterococcus faecalis and Enterococcus faecium isolates from clinical specimens and use of antimicrobials in five Nordic hospitals. J Antimicrob Chemother. 2003 Feb;51(2):323-31. doi: 10.1093/jac/dkg052.

16. Silva Garcez A, Núñez SC, Lage-Marques JL, Jorge AO, Ribeiro MS. Efficiency of NaOCl and laser-assisted photosensitization on the reduction of Enterococcus faecalis in vitro. Oral Surg Oral Med Oral Pathol Oral Radiol Endod. 2006 Oct;102(4):e93-8. doi: 10.1016/j.tripleo.2006.02.015.

17. Dametto FR, Ferraz CC, Gomes BP, Zaia AA, Teixeira FB, de Souza-Filho FJ. In vitro assessment of the immediate and prolonged antimicrobial action of chlorhexidine gel as an endodontic irrigant against Enterococcus faecalis. Oral Surg Oral Med Oral Pathol Oral Radiol Endod. 2005 Jun;99(6):768-72. doi: 10.1016/j.tripleo.2004.08.026.

18. Bonsor SJ, Nichol R, Reid TM, Pearson GJ. An alternative regimen for root canal disinfection. Br Dent J. 2006 Jul 22;201(2):101-5; discussion 98; quiz 120. doi: 10.1038/sj.bdj.4813819. Erratum in: Br Dent J. 2005 Oct 21;201(8):512.

19. Soukos NS, Chen PS, Morris JT, Ruggiero K, Abernethy AD, Som S, et al. Photodynamic therapy for endodontic disinfection. J Endod. 2006 Oct;32(10):979-84. doi: 10.1016/j.joen.2006.04.007.

20. Seal GJ, Ng YL, Spratt D, Bhatti M, Gulabivala K. An in vitro comparison of the bactericidal efficacy of lethal photosensitization or sodium hyphochlorite irrigation on Streptococcus intermedius biofilms in root canals. Int Endod J. 2002 Mar;35(3):268-74. doi: 10.1046/j.1365-2591.2002.00477.x.

21. Fonseca MB, Tessare Júnior PO, Pallota RC, Ferreira Filho H, Denardin OV, Rapoport A, et al. Photodynamic therapy for root canals infected with Enterococcus faecalis. Photomed Laser Surg. 2008 Jun;26(3):209-13. doi: 10.1089/pho.2007.2124.

22. Siqueira JF Jr, Rôças IN, Santos SR, Lima KC, Magalhães FA, de Uzeda M. Efficacy of instrumentation techniques and irrigation regimens in reducing the bacterial population within root canals. J Endod. 2002 Mar;28(3):181-4. doi: 10.1097/00004770-200203000-00009.

23. Berber VB, Gomes BP, Sena NT, Vianna ME, Ferraz CC, Zaia AA, et al. Efficacy of various concentrations of $\mathrm{NaOCl}$ and instrumentation techniques in reducing Enterococcus faecalis within root canals and dentinal tubules. Int Endod J. 2006 Jan;39(1):10-7. doi: 10.1111/j.1365-2591.2005.01038.x.

24. Gomes BP, Ferraz CC, Vianna ME, Berber VB, Teixeira FB, Souza-Filho FJ. In vitro antimicrobial activity of several concentrations of sodium hypochlorite and chlorhexidine gluconate in the elimination of Enterococcus faecalis. Int Endod J. 2001 Sep;34(6):424-8. doi: 10.1046/j.1365-2591.2001.00410.x.

25. Peters LB, van Winkelhoff AJ, Buijs JF, Wesselink PR. Effects of instrumentation, irrigation and dressing with calcium hydroxide on infection in pulpless teeth with periapical bone lesions. Int Endod J. 2002 Jan;35(1):13-21. doi: 10.1046/j.0143-2885.2001.00447.x.

26. Sassone LM, Fidel RA, Fidel SR, Dias M, Hirata RJ. Antimicrobial activity of different concentrations of $\mathrm{NaOCl}$ and chlorhexidine using a contact test. Braz Dent J. 2003;14(2):99-102. doi: 10.1590/s0103-64402003000200005. 
27. Guivarc'h M, Ordioni U, Ahmed HM, Cohen S, Catherine JH, Bukiet F. Sodium hypochlorite accident: a systematic review. J Endod. 2017 Jan;43(1):16-24. doi: 10.1016/j.joen.2016.09.023.

28. Vianna ME, Gomes BP, Berber VB, Zaia AA, Ferraz CC, de Souza-Filho FJ. In vitro evaluation of the antimicrobial activity of chlorhexidine and sodium hypochlorite. Oral Surg Oral Med Oral Pathol Oral Radiol Endod. 2004 Jan;97(1):79-84. doi: 10.1016/s1079-2104(03)00360-3.

29. Menezes MM, Valera MC, Jorge AO, Koga-Ito CY, Camargo CH, Mancini MN. In vitro evaluation of the effectiveness of irrigants and intracanal medicaments on microorganisms within root canals. Int Endod J. 2004 May;37(5):311-9. doi: 10.1111/j.0143-2885.2004.00799.x.

30. Vianna ME, Horz HP, Gomes BP, Conrads G. In vivo evaluation of microbial reduction after chemo-mechanical preparation of human root canals containing necrotic pulp tissue. Int Endod J. 2006 Jun;39(6):484-92. doi: 10.1111/j.1365-2591.2006.01121.x.

31. Garcez AS, Nuñez SC, Hamblin MR, Ribeiro MS. Antimicrobial effects of photodynamic therapy on patients with necrotic pulps and periapical lesion. J Endod. 2008 Feb;34(2):138-42. doi: 10.1016/j. joen.2007.10.020.

32. Siqueira JF Jr, Paiva SS, Rôças IN. Reduction in the cultivable bacterial populations in infected root canals by a chlorhexidine-based antimicrobial protocol. J Endod. 2007 May;33(5):541-7. doi: 10.1016/j.joen.2007.01.008.

33. Wainwright M. Photodynamic therapy: the development of new photosensitisers. Anticancer Agents Med Chem. 2008 Apr;8(3):280-91. doi: 10.2174/187152008783961888.

34. Ghinzelli GC, Souza MA, Cecchin D, Farina AP, de Figueiredo JA. Influence of ultrasonic activation on photodynamic therapy over root canal system infected with Enterococcus faecalis--an in vitro study. Photodiagnosis Photodyn Ther. 2014 Dec;11(4):472-8. doi: 10.1016/j.pdpdt.2014.07.004.

35. Wang $Y$, Huang $X$. Comparative antibacterial efficacy of photodynamic therapy and ultrasonic irrigation against Enterococcus faecalis in vitro. Photochem Photobiol. 2014 Sep-Oct;90(5):1084-8. doi: 10.1111/php.12293.

36. Rödig T, Endres S, Konietschke F, Zimmermann O, Sydow HG, Wiegand A. Effect of fiber insertion depth on antibacterial efficacy of photodynamic therapy against Enterococcus faecalis in rootcanals. Clin Oral Investig. 2017 Jun;21(5):1753-9. doi: 10.1007/s00784-016-1948-3.

37. Lam M, Jou PC, Lattif AA, Lee Y, Malbasa CL, Mukherjee PK, et al. Photodynamic therapy with Pc 4 induces apoptosis of Candida albicans. Photochem Photobiol. 2011 Jul-Aug;87(4):904-9. doi: 10.1111/j.1751-1097.2011.00938.x.

38. Verza SG, Silveira F, Cibulski S, Kaiser S, Ferreira F, Gosmann G, et al. Immunoadjuvant activity, toxicity assays, and determination by UPLC/Q-TOF-MS of triterpenic saponins from Chenopodium quinoa seeds. J Agric Food Chem. 2012 Mar;60(12):3113-8. doi: 10.1021/jf205010c.

39. Mahdi Z, Habiboallh G, Mahbobeh NN, Mina ZJ, Majid Z, Nooshin A. Lethal effect of blue light-activated hydrogen peroxide, curcumin and erythrosine as potential oral photosensitizers on the viability of Porphyromonas gingivalis and Fusobacterium nucleatum. Laser Ther. 2015 Mar 31;24(2):103-11. doi: 10.5978/islsm.15-OR-0.

40. Siddique R, Nivedhitha MS. Effectiveness of rotary and reciprocating systems on microbial reduction: A systematic review. J Conserv Dent. 2019 Mar-Apr;22(2):114-22. doi: 10.4103/JCD.JCD_523_18. 